\title{
Refugee Crisis and the Role of NGO Lobbying in Florida
}

\author{
Vishnu Muraleedharan \\ Kaunas University of Technology \\ A. Mickevičiaus 37, LT-44244 Kaunas, Lithuania \\ Thomas Andrew Bryer \\ The University of Central Florida \\ 4000 Central Florida Blvd, Orlando, FL 32816, United States \\ cross $^{r e f}$ http://dx.doi.org/10.5755/j01.ppaa.19.1.25148
}

\begin{abstract}
War, domestic violence, and economic instability in a country force its residents to flee their homeland and their place of birth to a different part of the world to save their lives, and around 70.8 million people have been displaced across the world (UNHCR, 2019). It is also a fundamental fact that women and children who have fled in this manner have been subject to various forms of violence and torture during their journey. Refugees are increasingly interested in emigrating to the United States of America, given the political and economic importance of the nation. Nevertheless, the United States has a strict legal system in place to prevent uncontrolled immigration, and hence the refugees face a variety of problems in order to travel to it. Refugees, particularly those travelling tens of thousands of kilometres are from Central American countries, Africa, Iran, and Syria, have arrived in many towns along the US-Mexico border. Increasing numbers of refugees force governments of the receiving countries to provide accommodation, food, and other facilities, which causes an inevitable financial crisis in the receiving regions. In such cases, the non-governmental organizations (NGOs) play a significant role in helping refugees with various types of assistance, and it is important to analyze the human rights activities of NGOs. NGOs have been a lobbyist in influencing legislators through a variety of political consultations and creating laws that protect refugees. It is crucial that NGOs can influence the Government level and various types of Cabinet Meetings, to study the issues of refugees and provide different kinds of possible support and assistance through their advocacy activities. The influence of the new media technologies in this twenty-first century has increased the opportunity to understand the lives of different people from different parts of the world and conduct various socio-political debates on global issues, such as the refugee crisis. Therefore, we need to evaluate the role of the social media of NGOs as a lobbyist in advocacy on addressing the refugee crisis. The article aims to identify the role of NGOs in addressing the migrant crisis and upholding the sanctuary policy in Florida that facilitates migrant integration. Research methods include a qualitative interview with the Florida Immigrant Coalition (FIC) and analyzing its social media discourse. The anti-sanctuary bill passed by the Florida state legislature were analysed; the analysis shows that the advocacy for the refugee crisis by NGOs using social media platforms increases civic participation. Such activism has a significant role in influencing policy framework on combating the crisis of refugee integration.
\end{abstract}

Keywords: refugee crisis, lobbying, advocacy, decision making, public policy, Florida.

Raktažodžiai: pabėgèlių krizè, lobizmas, gynimas, sprendimu prièmimas, viešoji politika, Florida. 


\section{Introduction}

The United Nations High Commissioner for Refugees (UNHCR, 2019) identifies that during the last two decades on the global level, many people have been displaced forcibly from their domestic locations due to civil wars, ethnic cleansing, and internal crises. In 1997 about 33.9 million people were displaced, and in 2019, about 70.8 million people were displaced in various parts of the world. This increase occurred mainly during the period between 2001 and 2015 due to conflicts in Syria, Iraq, Yemen, and Sub Saharan African countries. According to UNHCR (2011), around 20 people are getting displaced every minute of the day. Many countries across the globe came together to relocate these people, especially after the 2001 war on terror, which led to the displacement of people in the United States of America, which admitted the highest number of refugees $(96,900)$. UNHCR (2011) defines refugee resettlement "as an important expression of international solidarity and responsibility-sharing, as it provides international protection to meet the specific needs of vulnerable people whose life, liberty, safety, health, or other fundamental rights are at risk in the country where they have sought refuge." Ostrand (2015) finds that the United States of America (USA) and the United Kingdom are the top single states for bilateral donors in humanitarian aid. Asylum is a form of protection based on the principle of nonrefoulement and internationally or nationally recognized refugee rights (Eurostat, 2014). While temporary protection grants the right to enter or remain in a country for a limited time due to the risk of serious harm in a person's home country. It is the possible means for providing protection and usually granted to a large group of people based on extraordinary and temporary conditions in their country of origin (Orchard et al., 2014). Non-Governmental Organisations (NGOs) are the main organizations that help refugees to integrate into the host country. They are the third sector organizations that have their own identity, specific objectives and interests within a legal framework that operates for the emancipation of the society. NGOs are non-profit organizations in which members voluntarily work in order to accomplish a common goal, which tries to influence the policies and programs of the government's and international organizations by lobbying officials and policymakers (Seliger, 2003).

Traditionally NGOs are perceived as the major actor in the third sector area, which tries to influence the liberation of the deprived sections of the society. NGOs also act as a vital agent during incidences of natural calamities and disasters, thereby providing the role both as a developmental and crisis actor and also as promoting policies through advocacy (Lewis, 2010). Figure 1 shows the total number of unauthorized immigrants in the USA. In 2012 and 2016, the number of unauthorized immigrants was 58238 and 84994, respectively. However, in 2017 it decreased and amounted to 50479. The majority of unauthorized immigrants settle in states such as California, Texas, Florida, New Jersey, Georgia, North Carolina, Arizona, and Washington.

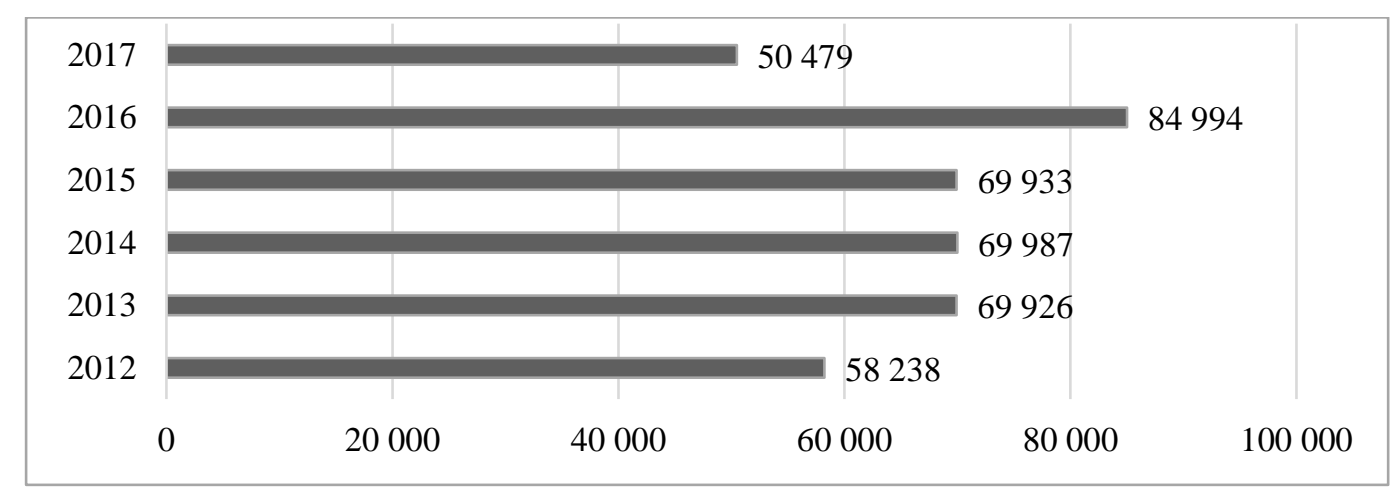

Fig. 1. Number of Unauthorized Immigrants in the USA

Source: Department of State, Bureau of Population, Refugees, and Migration Office of Admissions - Refugee Processing Center, USA 
Any action that stands towards supports, advocates for, favours, or appeals for or campaigns in lieu of others can be called advocacy. Geddes (2000) states that the safety of fragile and marginalized immigrants' freedoms is hindered. Prospects for pro-migrant lobbying have already appeared to Europeanized powers and responsibilities defining transnational arenas and routers of global pro-migrant advocacy organizations and partnership-building possibilities to EU entities. Integration statements centre on more European countries in the belief that bureaucrats, magistrates, and European parliamentarians can deliver a genuinely radical alternative to both the lowest shared denominator Local authority-based policy-making. Specifically, what we see from the Australian case of asylum advocacy groups is confirmation of local advocacy in which community groups or alliances were capable of achieving positive results in terms of pressing for a substantial political reform by bringing on existing operatives such as news media.

The research object of this article is the lobbying of NGOs.

The article aims to analyze refugee crisis management, with the focus on NGO lobbying mechanisms primarily through advocacy for sanctuary city policy and social media activism.

This article sets the following tasks:

1. To address the significance of NGOs in the refugee crisis;

2. To access the advocacy strategies of NGOs for lobbying on the migrant crisis through social media platforms.

In order to address the tasks above, the paper conducted an empirical study.

The article argues that due to the lobbying mechanisms of NGOs and their advocacy activities on social media platforms, migrant integration through sanctuary city policy significantly changes the perception of the society of the refugee crisis and increases awareness of the need for protecting the sanctuary city. The article presents the results of the original research, including the analysis of primary sources through an empirical study based on primary data collected by an interview from a leading NGO in Florida, which supports sanctuary city policy. The paper includes an introduction into the refugee crisis, indicates the research gap and presents a relevant literature review, theory, method, lobbying policy, activism strategies, the study on Florida Immigrant Coalition (FCI), followed by a conclusion and references.

\section{Research Gap}

Non-governmental organizations are strategic organizations with an alliance, technical campaigning, and multi-level lobbying for addressing various types of social development. Its functions and advocacy systems gained extensive exposure over the past few decades, especially on participation during multiple crises, including migration-related concern. An advocacy system is a broad term used to describe an infrastructure in advocating across national boundaries with members motivated by shared values rather than competent or content issues. The degree of cohesiveness around multinational participants differs depending on the organizational agenda. The political discourse of conflict and struggles receives attention from various approaches in any nation. Particularly proactive political life by activism related to the rights of minorities, asylum seekers and refugees, the indigenous population receives considerable attention. Eventually, the involvement of NGOs in the protection of asylum seekers and advocacy expand unstructured surveillance of governmental action. Such advocacy measures are significant accomplishments, and the public policy becomes much more structured and favourable for the marginalized community. There were some studies on the importance of NGOs. Salamon and Anheier (1999) said that advocacy policies of NGOs try to achieve their objectives and vested interest in the overall development of society by coordinating with national (or regional) policy. In the developing world, the NGOs play a vital role, especially during the times of disaster or natural calamities, to protect the vulnerable sections of the societies, where the national and local government failed to deliver the required resources (Bromideh, 2011). According to Barrett (2001), most of the developmental aids of the US government for the developing and poor counties are carried by NGO strategies. Nevertheless, studying the lobbying 
practices of NGOs requires much more attention, particularly exploring the policies employed by the NGOs in influencing the political agenda and decisions using their lobbying system.

Florida State in the USA has been one of the states that faces challenges of refugee integration into society. There is a considerable lack of study on the NGO lobbying in Florida to tackle issues like this. In the opinion of Baron (2019), one of the challenging aspects of the modern democratic system for the lobbying associations and groups is coalition politics and their diverse ideological and political interest. It makes the success of lobbying very complex and unpredictable, which in turn requires to depend upon the policies and specific programs of the governments (Mahoney, 2007). Unerman et al. (2006) state that if the broad or medium and high roles on the purview of responsibility tasks are approved, it is hard to argue that NGOs must (or would) be responsible for the effect that their advocacy operations can have on a wide variety of interested parties. Nonetheless, NGOs are accountable for both the broader, direct and indirect effects of the advocacy initiatives. Bolten et al. (2007) found that mainly due to uncertainty, non-governmental organizations minimize not just lobbying but any parliamentary interaction as well. In such circumstances, NGOs have been increasing their advocacy activities via new media, primarily through social media platforms in recent years. Keck et al. (1999) say that the central online campaigning should ensure individuals with accessibility to relevant information, various ways of framing problems that involve different sorts of information. Sometimes geographic proximity, globalization, the multiplicity of languages and cultures, and the expense of fax, mobile, postal, or air travel render the activism in the social media realm. Whenever a government breaches or refuses to acknowledge its citizens' privileges, in national political or legislative arenas, people coordinate with third sector organizations. Voices of Young Refugees in Europe (2012) found that people's involvement has raised awareness of best practices that improve young immigrants' social integration through NGO advocacy. Social networking platforms such as Twitter, Instagram, YouTube, blogs, LinkedIn were used for activism, awareness sharing, and opinion enhancing. Even though this aspect of NGO lobbying has been explored in the academic arena, the aspect of lobbying concerning the sanctuary mechanism and the role of new media mechanisms in influencing the policy decisions and public perception have not been explored to a great extent. Hence it is essential to explore the lobbying and new media mechanism of NGOs in order to tackle refugee crisis integration and sanctuary movement.

\section{Theory of the research: Constructivist Theory}

The 1960s was a period for a wave of significant theories in Social Science and constructivism as one of the most dominant theories in this regard (Gubirium and Holstein, 2008). The Constructivist theory is characterized by an emphasis on the importance of normative as well as material structures, on the role of identity in shaping political activities and on the mutually constructive relationship between agents and structures. Constructivism led to the shifting away from the previous model of abstract philosophical argument towards the study of human discourse and practices. It evolved and manifested through a variety of research in Social Science, ranging from societal issues to the "social construction of mind" (Coulter, 2001) and "self" and has set as a mechanism for carrying out "empirical research" (Wiley, 1994). The constructivists use ontological mechanisms to explain and interpret aspects of world politics that were anomalous to neoliberalism and neorealism. Constructivists use interpretive, discursive, and historic modes on analysis to enhance their empirical explorations. However, like other theories, constructivism came under criticism and was termed as "radical and conservative, liberating, managerial and oppressive, cancerous...." (Gubirium and Holstein, 2008). The study overviewed the constructivist theory and its analyses of the refugee crisis and the role of NGOs for migrant assimilation through sanctuary cities and mediatized political communication through the mechanisms of new media. Thus, by employing the constructivist theory in refugee crisis management and the role of NGOs for the refugee assimilation and integration through their mediatized political communication and lobbying mechanism as it will facilitate the constructive relationship between the agents and structures, i.e., between the NGOs and the political actors which can facilitate immigrant integration and assimilation. Also, the constructivist theory 
emphasises the historical aspect that enables to understand the evaluation of the refugee movement and the sanctuary bill policy and thus to find a possible solution based on historical imperatives. Thus, constructivism is a possible theory that explains how and why the refugee crisis emerged and the role of NGO as a catalyst for refugee crisis management and political decision making.

\section{Methods}

Migration and the related refugee crisis are some of the most challenging global issues in the present century. Among the different political actors in combatting the refugee crisis and the integration of refugees, NGOs also play a vital role. Lobbying is one of the primary mechanisms that the NGOs employ for accomplishing migrant integration and positive policy decisions. Florida, a southeastern US state, has a population of 20.61 million, which has given high regard and attention to the refugee/asylum applicants and immigrants. However, during the Florida State election in 2018, Republican Ron De Santis was elected as the new Governor of Florida. During the legislative period of June 2019, the Florida legislature passed the Senate Bill (SB) 168, which is the anti-sanctuary bill banning the Sanctuary cities, which protects the immigrants. Before the passage of the Anti-Sanctuary bill, Florida had 16 sanctuary cities, including Orlando. In order to understand the mechanisms of lobbying of NGOs to combat the refugee crisis, this paper examines the sanctuary city policy of USA, and the lobbying techniques employed by the NGOs in influencing the political communication for pro-immigrant policies and migrant integration. Furthermore, in order to identify the activism of NGOs, the article analyses the Facebook discourse of Florida Immigrant Coalition during the period from November 01, 2018, till April 30, 2019, and identifies the new media strategies which shape the public perception towards immigration and to disseminate the pro and anti-immigrant governmental mechanisms and policy frameworks. The main research method includes empirical study based on primary data collected from one prominent NGO, i.e., Florida Immigrant Coalition, which is the foremost advocate of sanctuary city policy and immigrant integration. The significance of selecting this particular NGO is since it is a conglomeration of all the major NGOs in the field of immigration, and the members of those NGOs have representation in the board of directors of the Florida Immigrant Coalition. Also, the mechanism of selecting Facebook discourse for social media analysis is because, unlike other social media platforms, Facebook has more connectivity and public reach. Due to its specifications like the option for sharing in various groups, Facebook Live, and the aspect of sharing lengthy videos with higher dimensions that support different video formats and the possibility of writing lengthy comments and posts with more characters. Thus, choosing Facebook for the social media discourse of the Florida Immigrant Coalition is suitable here.

\section{Understanding the lobbying mechanism of Non-Governmental Organisations}

War, internal rebellion, political and social upheaval in various parts of the world, particularly in the developing and under-developing countries, led to the displacement of people and increased the number of migrants who look for a safer haven. In the USA, the state of Florida always has a welcoming policy towards migrants and their integration. The election of the Republicans in 2018 led to the changes in this welcome policy, especially with the passing of the SB 168, which limited the immigrants and abolished the Sanctuary policy. In this circumstance, it is significant to analyze the role of NGOs, primarily through their lobbying strategy and advocacy activities for immigrant integration and protecting immigrant rights. Lobbying is one of the most important and frequently used policy by NGOs for accomplishing their objectives. The actions of a group who have vested political or social interest which tries to influence the governmental policies and programs for achieving their specific interest. Lobbying as an act of influencing governmental policies is carried out by a diverse group of entities which tries to bring changes in the governmental policies (Baron, 2019). There are various definitions of lobbying, and UK Public Affairs Council considers lobbying as "in a professional capacity, attempting to influence, or advising those who wish to influence the 
government, parliament, the devolved legislature, or administrations, regional or local government or public bodies on any matter within their competence."

California Constitution of 1879 considers lobbying as a tool to "obtain or seeks to obtain money or other things of value from another person upon a pretence, claim, or representation that he can or will improperly influence in any manner the action of any member of any legislative body regarding any vote or legislative matter is guilty of a felony." Hall and Deardorff (2006) find that the lobbying process is a mutually beneficial action as it enables the lobbyist to achieve their vested interest, whereas it provides the lawmakers with the required knowledge and expertise on the specific topic or issue, which is mostly not directly accessible for them. It enables the lobbyist to provide the necessary expertise and knowledge to the legislators concerning valuable political resources in return for the specific benefits which they value. Miller and Dinan (2008) perceived lobbyists as advisory activists who provide their expertise and personal connections with policymakers by affecting governmental decision- making and was acting as an instrument of an essential source of information. This kind of expertise mainly concerns issues or aspects, which enables them to convince the policymakers (Crombez, 2002). It facilitates them to continue bidding up for the specific objectives which the group stands for or till the drying up of the economic resources of the group which they can allocate for the specific cause (Snyder Jr, 1991). Therefore, it is significant that the advocacy activities of NGOs for the enhancement of human rights, especially securing and protecting the rights of the migrants and refugees, can ease the tensions with political administration (Battistella, 1993).

\section{NGO advocacy strategies for immigrant integration}

Different countries face various challenges in solving migrant crisis either due to the lack of proper policy mechanisms or with the ideological and political objection towards migrants in the receiving nations. In such circumstances, NGOs become one of the most prominent actors to support the integration process. The state of Florida adopted the sanctuary policy mechanism for refugee management and integration for years. The concept of sanctuary was first used in the immigration context during the 1980s to refer primarily to the efforts of churches and cities to assist the refugee and asylum applicants who moved from Central America. The word sanctuary means shelter or a support place for the deprived, and this term receives more attention and significance in the political arena after the mass immigration crisis across the globe. NGOs and civil society organizations conduct programs like campaigning, social activities, awareness-raising events, etc. as part of advocacy for lobbying. These kinds of activism try to insist on the government and other like-minded organizations support and promote the policies for assimilating the immigrant population and also to maintain and retain sanctuary policies and cities in Florida. For several centuries, different counties, districts, and towns in the US have enacted distinct strategies and laws to safeguard their inhabitants independently of their immigration status, given the reality that multiple political parties promote the concept of America First. In the US, elections in 2007 and 2017, both Republican and Democratic parties raised the question on the aspect of support to the undocumented immigrants and allowed them to have all the rights like ordinary immigrants in the USA.

Villazor (2008) uses the word 'sanctuary city' to describe 'individual municipalities which adopted the policy of sanctuary, non-cooperation or confidentiality policies for undocumented residents, which has an inclusive legislations and are deemed as sanctuary cities. Nevertheless, the informal sanctuary cities are in which 'there is no resolution or policy on paper but instead where their classification based on observed actions such as lack of enforcement and the local officials forbids doing the investigation on unauthorized immigrant's and such cities will not be able to get city level funds and benefit' (O'Brien et al., 2019). In order to enhance the capacity of lobbying, NGOs implied the strategy of advocacy for influencing politicians, society, and stakeholders. Stromback (2007) explains that the media is the most important source of information and channel of communication between citizens, political institutions, and its various actors. One of the significant innovations of the 21 st century is the discovery and the growth of the internet and social media activities. Unlike the traditional media, which have their own ideological and political affiliations and 
allegiance, the new media, with its lesser political allegiance, makes information on any issues or events across the globe more transparent without any delay. Hence Van Dijck (2013) believes that the growth of the internet and social media can challenge political preferences and makes the discussion more democratic and rational than previous centuries. The development of online platforms like Facebook, Twitter, and YouTube enabled the general public to respond and exhibit their opinions on time and enables them to communicate with the political administration directly.

\section{Case study: Advocacy of Florida Immigrant Coalition}

NGOs face challenges in establishing their lobbying system in the state of Florida for dealing with migration issues due to the lack of legitimate political attention. In such circumstances, the usage of social media as an advocacy platform becomes more relevant and vital. The advocacy activities for increasing society's awareness, empathy, cooperation on migrant integration is achievable via the Facebook platform of Florida Immigrant Coalition (FIC). Florida, a southeastern US state with a population of 20.61 million, has given rise to the importance of the refugee/asylum applicants. Before the passage of the Anti-Sanctuary bill, Florida had 16 sanctuary cities, including Orlando. Figure 2 shows the number of undocumented immigrants in Florida from 2000 to 2015. The advocacy activities promote the social media profile of concerned NGOs, and they increase the reach to society on various social affairs. They were also persistent in making an amicable solution and conducive environment for the immigrants in the United States through collective action. The FIC, founded in 1996 and actively lobbying, collaborates with other like-minded organizations for influencing the policy decision conducive for the immigrants and also caters to the needs of migrants and refugees. Specifically, access to education, health care, employment including farm work is provided in order to prevent the deportation and detention by the federal agencies and police, to make the programs for allow the undocumented immigrants to documented immigrants and to transform permanent residents to citizens.

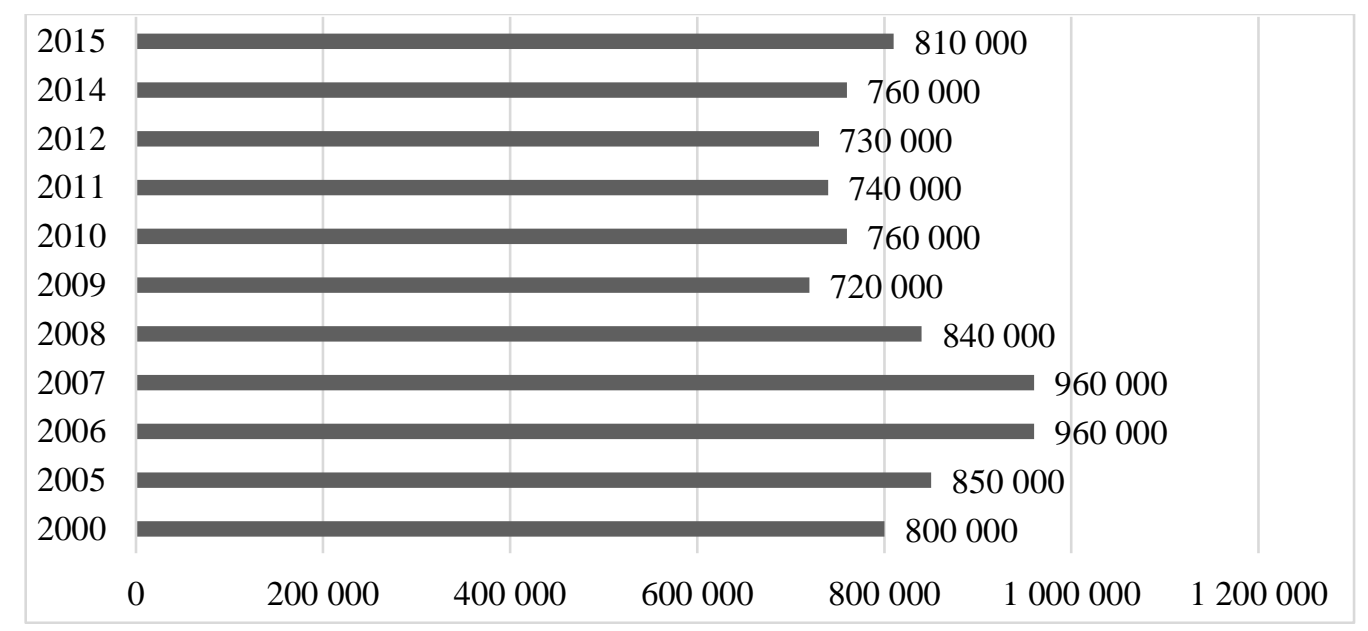

Fig. 2. Number of undocumented immigrants in Florida from 2000-2015

Source: Estimates of the Unauthorized Immigrant Population Residing in the United States; U.S Department of Homeland Security

\section{Findings of the study}

In order to find out the activities of the Florida Immigrant Coalition for assisting refugees, this paper had conducted a primary interview using a semi-structured questionnaire, with the NGO's lead organizer and membership director who has been part of this NGO for over ten years. The interview from the lead organizer and membership director in the NGO focused on the significant aspects of 
lobbying for the refugee crisis and the integration and assimilation mechanisms. While discussing the central activism, the respondent mentioned their success in defeating the anti-immigration bills and policy mechanisms in the Florida State legislature with the help of the legislators and policymakers, one of the significant lobbying successes. At the end of 2017, the Florida State Legislature had introduced the anti-sanctuary and anti-immigration bills such as House Bill (HB9) and Senate Bill (SB308) and HB45/SB212, in which are intended to abolish the sanctuary bill. However, due to the active participation of FCI through their lobbying mechanisms and advocacy practices, in March 2018, these two bills were successfully denied its access to come into practice. There were seven other anti-sanctuary bills, too, and they also did not come into power. The FCI had influenced not only the legislative members but also had influenced media and the general public over the need to stabilize sanctuary policy for refugees. Different media channels such as the Miami Herald, CBS Miami, and WUSF News had profoundly given attention to the enormous lobbying and advocacy activities done by the FCI. The respondent also acknowledged that they receive support from various legislatures who have a similar approach towards supporting sanctuary bills, and hence the FCI was able to proceed with the advocacy for migrant rights. Figure 3 shows the various advocacy activities initiated by FCI.

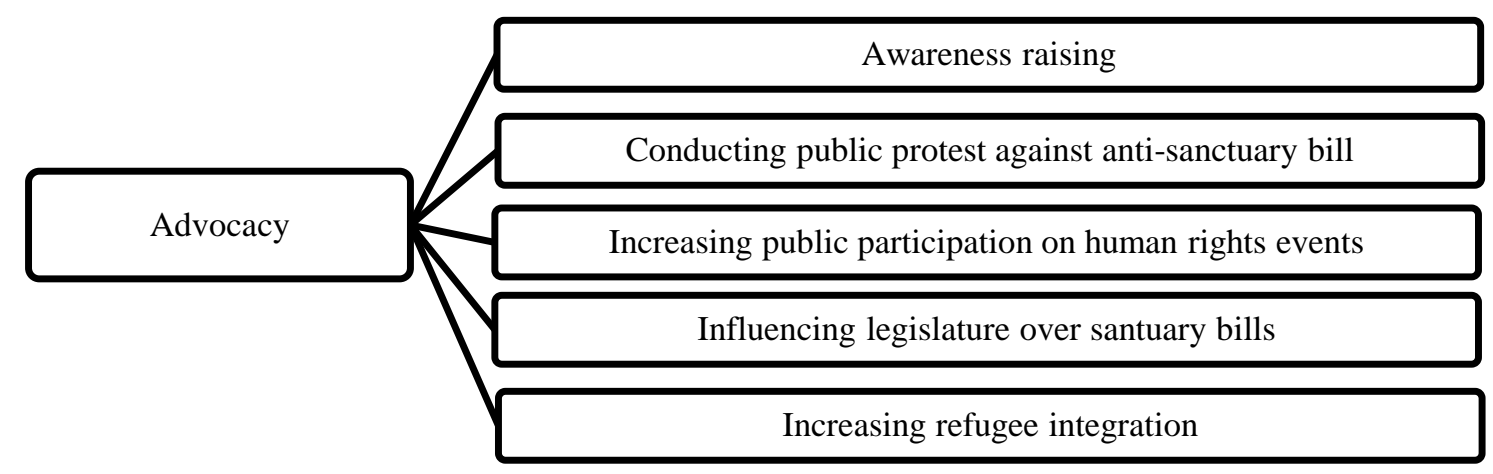

Fig. 3. Advocacy activities of FCI

Source: Authors

Apart from the lobbying activities, the organization also provides direct guidance and assistance to immigrants and their families. The respondent confirms that they are working on increasing collaboration with all major NGOs in the state of Florida, who are in favour of migrants' rights, thereby creating a broader platform for raising the voices of the deprived has been taken as an essential task. Also, enhancing awareness and information dissemination for refugee integration is carried out through their social media platforms. Through broadcasting and live streaming of various campaigns and protests by this NGO has increased society's involvement in humanitarian aid. In order to create a friendly atmosphere for the migrants, FCI also conducts various programs specifically for the local community to help refugees, primarily assist them for their self-development and integration into the social framework. Through the community integration events, FCI also increases the chance for migrants to assimilate correctly into their new society without hindrances and psychological trauma. Hence, the overall interaction with the FCI respondent shows that third sector organizations have a higher significance in lobbying and advocacy initiatives for assimilation and development of refugees and migrants into the receiving society.

In order to find out the activism of FCI using their Facebook platform, this article conducted an empirical analysis by observing their various social activities posted on the page for six months that is from November 1, 2018, until April 30, 2019. The study aims to identify how their posts and views are mobilizing people's participation in refugee crisis management, especially in the state of Florida. By examining the comments of the public on FCI activities, the article was able to explore the influence of new media technology on lobbying and advocacy for social inclusion. Through such a study, it is adequate to find out the information on how many people have participated in issues on 
refugee or migrant crisis during these periods in the form of sharing the post, likes and commenting on incidences. Also, their participation in promoting the idea of a welcoming approach to migrants and the changes that have taken place in the form of the new policy, so that it is suitable to find the role of advocacy. The study looked at the NGO's active participation and involvement in advocacy through their awareness-raising events, conducting protests against the anti-sanctuary bill, involving increased public opinion on the refugee crisis, influencing legislative policies, and finally, enhancing integration of migrants into the community in Florida. Figure. 4 shows the results of the analysis based on the six variables given above. During these six months, 304 relevant posts directly related to migration in the U.S, and among them, 201 posts related to justice, 199 was on NGO activism, 142 were on deportation, seven were on membership, and three were on the NGO's Fundraising aspect for maintaining their activities. Along with the number of post in the NGO's page, it is relevant to identify the number of 'likes' and shares too since it is an essential component in the new technology to validate the public participation and their attention and detailing such issues via social media and the dissemination of the idea of concern towards the immigrant crisis and regulations.

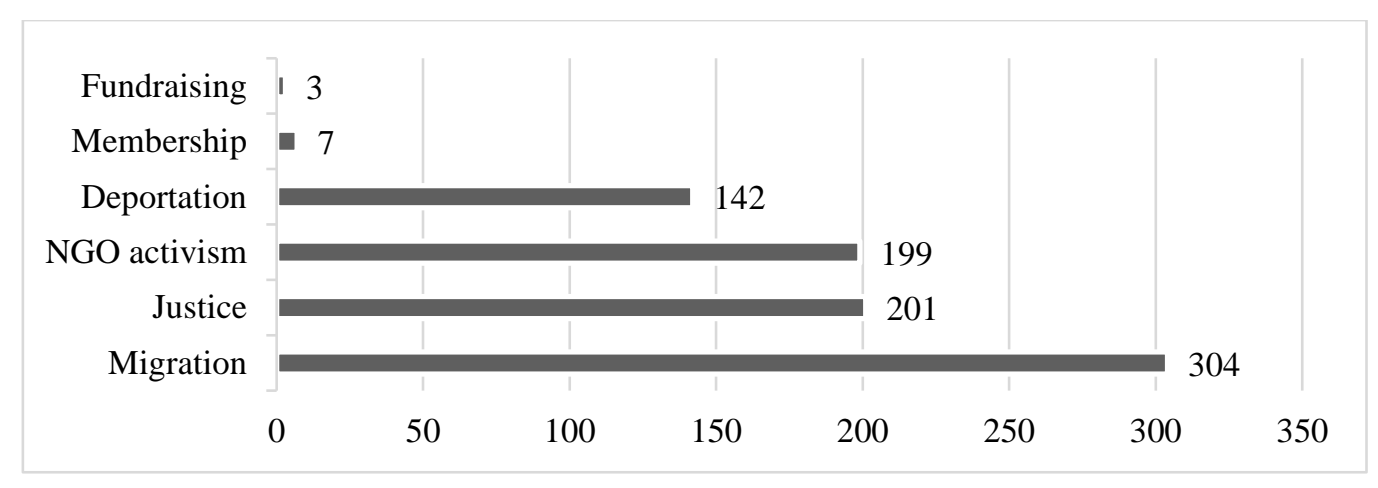

Fig. 4. Distribution of post shared in the NGO from 01 November 2018-April 20, 2019

Source: Facebook page, Florida Immigration Coalition

Table 1 clearly shows the broad participation of people in FCI activism over social media since for all the social media posts by the NGO, and there were 5,407 likes and 5,888 shares of the post.

Table 1. Number of posts viewers from 01 November 2018-April 20, 2019

\begin{tabular}{|c|c|}
\hline Characteristics & Numbers \\
\hline Number of likes & 5407 \\
\hline Number of sharing & 5888 \\
\hline
\end{tabular}

Source: Facebook page, Florida Immigration Coalition

The Facebook page of the Coalition was established on February 1, 2005, and have 13,551 active followers. The comments that appeared on social media show the intensity of the issue regarding the migration and sanctuary policy and how the individuals and society are influenced. From the comments posted by viewers, it is clear that there is the active participation on the part of society as, during the six months, there are around 5,407 likes for the posts shared and 5,888 shares for the posts uploaded by the Coalition in terms of discussing the issues of the immigration crisis. For example, the following comment represents the variable migration and justice and shows the empathy of the public towards the immigrants: 
"Thank you, Rep. Cummings, for defending the rights of these people who need humanitarian aid, not tear gas."

(Anonymous 1, 26 November 2018 Facebook, FIC)

The comment shows the opposition towards the anti-immigration policies. It also shows the citizen's confidence in the political and legal system and the belief that the justice mechanism can lead to the revival and rectification of the political process and decision making. Another comment represents the deportation variable and shows the desperate state of family separation caused by federal immigration policies, which led to the family separation. It shows the penetration of NGO activism through the new media mechanisms, which led to citizen participation and awareness about the immigration policies and the state of hardships the immigrants encounter in the United States.

"SB 168 will erode trust in law enforcement and hurt our communities. Connect with your Senator and tell them to stop the anti-immigrant bill SB 168 ".

(Anonymous 2, 20 February 2019 Facebook, FIC)

The following comment represents the deportation variable and shows the desperate state of family separation caused by federal immigration policies, which led to the family separation. It shows the penetration of NGO activism through the new media mechanisms, which led to citizen participation and awareness about the immigration policies and the state of hardships the immigrants encounter in the United States.

"Omg... Have a heart and let this woman see her baby".

(Anonymous 3, 17 December 2018 Facebook, FIC)

These comments of Facebook followers show that they support the inclusion of immigrants and thus would like to show their opposition against anti-migrant policies by the Federal government. It mainly facilitates employing joining the organization by the membership fairs and events and also by contributing to the fundraising mechanisms of the Coalition, thereby facilitating for advocacy and lobbying activities of the NGO. Thus, from the above qualitative content analysis of the interview and Facebook discourse of the Florida Immigrant Coalition, it can be evaluated that the NGO was actively lobbying and utilizing its social media platform for reducing the refugee crisis and for promoting refugee integration and assimilation policy mechanisms and for combating anti-sanctuary policy measures. With the defeat of various anti-sanctuary bills that floored in the Florida State legislature. However, further analysis after the state election and the Republicans to the power the situation got changed. The policy on the transformation of the states from sanctuary to non-sanctuary state status sanctioned. It facilitated the introduction of two anti-sanctuary bills, i.e., Senate Bill (SB 168) and the House Bill (HB 527). SB 168 proposed by Senator Joe Gruters (R-Sarasota) and voted out 9-8, whether as HB 527, which sponsored by Representative Cord Byrd (R-Neptune Beach) and voted out 12-6 which provides both these bills to go through the legislative screening for the final approval of the Governor. However, it was widely criticized and opposed mainly by the Florida Immigrant Coalition, together with the Southern Poverty Law Center (SPLC) and the American Civil Liberties Union (ACLU).

However, due to the political allegiance of the ruling party of the Florida legislature towards the Federal administration, the SB 168 signed by the Governor Ron DeSantis on July 14, 2019, which made the state of Florida an anti-sanctuary city and forced it to cooperate and align with the Federal Immigrant enforcement authorities. The far-reaching consequences might lead to a complete ban on the sanctuary policies of the state and local authorities, including the local authorities, state, and the universities and other institutions which support the sanctuary and pro-immigrant approach. It will also lead to local government and state authorities to honour and detain immigrant detainers which will enable the local county and other agencies to sign up an agreement with the Federal government for the reimbursement for holding the immigrant detainers and vest the authority to the Florida attorney general for the implementation of the aspects about the bill. Therefore, future 
research should focus on the new legal provisions and the enhanced mechanisms employed by the NGOs for combatting such policy measures.

\section{Conclusions}

The findings show that the socio-political unrest led to the displacement of people and needs to be recognized as a global crisis. It requires further study on the impact of the migrant crisis in developed and developing nations. It leads to a scenario of the refugee crisis who are seeking protection and asylum. The aspect of sanctuary policy in the United States, especially in the state of Florida, can act as an assimilating mechanism for refugee integration into society. Due to the changing political environment led to the anti-sanctuary mechanism in Florida deter refugee integration. However, third sector organizations, especially NGOs, act as a catalyst for the revival of the sanctuary mechanism and the refugee integration through their mechanisms like lobbying and mediatized political communication for policy formulation. One of the significant mechanisms is lobbying and as an essential aspect of any democratic process which allows citizens, NGOs and other socially committed organizations to use the lobbying platform to influence the political decision making through parliamentary proceedings. Concerning the aspect of immigration and sanctuary policies for supporting, promoting, and assimilating the immigrants, NGOs play a vital role in their advocacy activities. Besides, NGOs influence the public perception of refugees and their plight by using social media platforms is an essential area for society to involve in the advocacy. Their informal and formal activities gain more public opinion and involvement.

Such advocacy activities help the society to communicate and make necessary social movements with the help of NGOs and thereby challenge the governance on various societal issues. The use of new media technologies by third sector organizations like NGOs is necessary to mould possible outcomes. The Republicans under the Trump administration significantly affect the agenda on immigration, and the sanctuary policies across the nation have changed. It forced many states and counties to align with the national policies due to a lack of financial assistance from the Federal government. Therefore, this study shows that NGOs act as an influencing partner by lobbying and advocacy strategies for reviving the political process. In the state of Florida, NGOs play a significant role in advocacy for migrant rights and the enhancement of the human rights of refugees. They even enhance society's engagement in social media platforms by making campaigning. Such advocacy activities increase awareness of people on the need for addressing the refugee crisis as a human right, rather than a political stigma. Thus, this article tried to find out the influences of the role of NGOs on the lobbying aspects in order to combat the upcoming legislative measures and to sustain the immigration and sanctuary policies. From the analysis of the interview, the NGO is trying to lobby for sustaining the sanctuary status of the Florida state, thereby facilitating immigration and avoid the detaining of the illegal immigrants by the Federal agencies. Lack of proper classification of the conservative and liberal party followers' approach towards the refugee crisis, by looking at their social media involvement on the advocacy of FCI could be considered as a limitation of this study. However, this article shows that the lobbying activities and advocacy through social media play a pivotal role in the assimilation of immigrants and sustaining the sanctuary status of the states and counties.

\section{References}

1. Anonymous 1. Facebook: Florida Immigrant Coalition (accessed November 26, 2018).

2. Anonymous 2. Facebook: Florida Immigrant Coalition (accessed February 20, 2019).

3. Anonymous 3. Facebook: Florida Immigrant Coalition (accessed December 17, 2018).

4. Baron, D.P., 2019. Lobbying dynamics. Journal of Theoretical Politics, 31(3), pp.403-452.

5. Barrett, C.B., 2001. Food security and food assistance programs. Forthcoming in Handbook of Agricultural Economics, 2.

6. Battistella, G., 1993. The human rights of migrant workers: Agenda for NGOs. International Migration Review, 27(1), pp.191-201. 
7. Bromideh, A.A., 2011. The widespread challenges of NGOs in developing countries: Case studies from Iran. International NGO Journal, 6(9), pp.197-202.

8. California Constitution of 1879, "Constitution of The State of California," available https://www.cpp.edu/ jlkorey/calcon1879.pdf

9. Coulter, J. (2001). Book Review: Ian Hacking on Constructionism. Science, Technology, \& Human Values, 26(1), 82-86.

10. Crombez, C., 2002. Information, lobbying and the legislative process in the European Union. European Union Politics, 3(1), pp.7-32.

11. Department of State, Bureau of Population, Refugees, and Migration Office of Admissions Refugee Processing Center, USA. Available at https://www.state.gov/prm-funded-researchand-evaluation/prm-funded-evaluation/

12. Eurostat. (2014). "Glossary:Asylum", available at: http://ec.europa.eu/eurostat/statisticsexplained/index.php/Glossary:Asylum

13. Facebook page. Florida Immigration Coalition, available at: https://www.facebook.com/FloridaImmigrantCoalition/

14. Gubirium, J. F., \& Holstein, J. A. (2008). The constructionist mosaic. Handbook of constructionist research, 3-12.

15. Hall, R.L. and Deardorff, A.V., 2006. Lobbying as legislative subsidy. American Political Science Review, 100(1), pp.69-84.

16. Lewis, D., 2010. Non-governmental organisations, definition and history. International encyclopedia of civil society, pp.1056-1062.

17. Mahoney, C., 2007. Lobbying success in the United States and the European Union. Journal of Public Policy, 27(1), pp.35-56.

18. Miller, D. and Dinan, W., 2008. Corridors of Power: Lobbying in the UK. Observatoire de la société britannique, (6), pp.25-45.

19. O’Brien, B. G., Collingwood, L., \& El-Khatib, S. O. (2019). The politics of refuge: Sanctuary cities, crime, and undocumented immigration. Urban Affairs Review, 55(1), 3-40.

20. Orchard, C., Miller, A. and Chatty, D., 2014. Protection in Europe for refugees from Syria. Oxford, UK: Refugee Studies Centre.

21. Ostrand, N., 2015. The Syrian refugee crisis: A comparison of responses by Germany, Sweden, the United Kingdom, and the United States. Journal on Migration and Human Security, 3(3), pp.255-279.

22. Salamon, L. and Anheier, H., 1999. The third sector in the third world. International Perspectives on Voluntary Organisations, Earthscan, London.

23. Seliger, B., 2003. From Civic Organisation to NGOs in Germany: An Interest Group Analysis. International Area Review, 6(1), pp.53-68.

24. Stromback, J. (2007). Four Phases of Medianization. In An Analysis of the Medianization of Politics. Paper presented to the ICA Conference in San Francisco May.

25. Snyder Jr, J.M., 1991. On buying legislatures. Economics \& Politics, 3(2), pp.93-109.

26. UK Public Affairs Council. Lobbying definition, available at: http://www.citizenpower.co.uk/en/resources/lobbying-definition.html

27. UNHCR, 2011. UNHCR resettlement handbook. Resettlement Service, Division of International Protection. Geneva.

28. UNHCR, 2019.Figures at a glance, available at: https://www.unhcr.org/ph/figures-at-a-glance

29. Van Dijck, J., 2013. The culture of connectivity: A critical history of social media. Oxford University Press.

30. Villazor, R.C., 2008. What is a Sanctuary. SMUL Rev., 61, p.133.

31. Wiley, N. (1994). The semiotic self. University of Chicago Press. 
Vishnu Muraleedharan \& Thomas Andrew Bryer

\section{Pabėgèlių krizė ir nevyriausybinių organizacijų lobizmo vaidmuo Floridoje}

Anotacija

Karas, smurtas šeimoje ir ekonominis nestabilumas šalyje verčia jos gyventojus bėgti iš jų gyvenamosios vietos i kitą pasaulio kraštą tam, kad išgelbètų savo gyvybes. Visame pasaulyje iš iprastų gyvenamujų vietų perkèlè apie $70,8 \mathrm{mln}$. žmonių (UNHCR, 2019). Svarbu paminèti, kad kelionès metu moterys ir vaikai dažniau nei vyrai patiria smurtą, kankinimus. Vis daugiau pabėgèlių prašosi prieglobsčio Jungtinèse Amerikos Valstijose (JAV) dèl šalies politinès ir ekonominės svarbos pasaulyje. Nepaisant to, JAV galioja griežta teisinè sistema, skirta užkirsti kelią nekontroliuojamai imigracijai, todèl pabėgèliai, norèdami atvykti ị šalị, susiduria su ịvairiomis problemomis. Pabègèliai, ypač keliaujantys dešimtimis tūkstančių kilometrų iš Centrinès Amerikos šalių, Afrikos, Irano ir Sirijos, atvyko ị daugelị miestų, esančių palei JAV ir Meksikos sieną. Didèjantis pabėgèlių skaičius verčia priimančiųu šalių vyriausybes aprūpinti apgyvendinimu, maistu ir kitomis priemonėmis, o tai sukelia neišvengiamą finansinę krizę juos priimančiuose regionuose. Tokiais atvejais nevyriausybinès organizacijos (NVO) vaidina svarbų vaidmenị teikdamos pabėgèliams įvairių rūšių pagalbą, todėl svarbu išanalizuoti NVO veiklą žmogaus teisių srityje. NVO veikia kaip lobistai, norėdami paveikti istatymų leidejjus per ịvairias politines konsultacijas ir kurdami ịstatymus, saugančius pabėgèlius. Labai svarbu, kad NVO galètų daryti įtaką vyriausybės lygiui ir ịvairių tipų ministrų kabineto susitikimams, išsiaiškinti pabėgèlių klausimus ir suteikti ịvairią paramą bei atstovauti pabėgèlius. Naujų žiniasklaidos technologijų įtaka dvidešimt pirmame amžiuje padidino galimybę suprasti skirtingų žmonių iš skirtingų pasaulio šalių gyvenimus ir vesti ịvairius socialinius bei politinius debatus globaliais klausimais, tokiais kaip pabėgèlių krizè. Todėl turime įvertinti NVO socialinès žiniasklaidos, kaip lobisto, vaidmenį analizuojant pabėgèlių krizę. Straipsnyje siekiama nustatyti NVO vaidmenį sprendžiant migrantų krizę ir palaikant prieglobsčio politiką Floridoje, palengvinančią migrantų integraciją. Tyrimo metodai apima kokybinį interviu su Floridos imigrantų koalicija (FIC) ir jos socialinės žiniasklaidos diskurso analizę. Buvo išanalizuotas Floridos valstijos ịstatymai susiję su prieglobsčio klausimais. Analizė rodo, kad nevyriausybinès organizacijos, naudodamos socialinès žiniasklaidos platformas, gina pabėgėlių krizę, skatina pilietinį aktyvumą. Toks aktyvumas vaidina svarbų vaidmenį darant įtaką politinei kovai su pabėgèlių integracijos krize.

Vishnu Muraleedharan - politikos mokslų doktorantas, Socialinių ir humanitarinių mokslų ir menų fakultetas, Kauno technikos universitetas, Lietuva.

email: vishnuvalayil@gmail.com

Thomas Andrew Bryer - politikos mokslų daktaras, profesorius, Centrinès Floridos universitetas, Jungtinès Amerikos Valstijos.

email: thomas.bryer@ucf.edu

Vishnu Muraleedharan - is a third-year PhD researcher in Political Sciences at the Faculty of Social Sciences, Arts, and Humanities, Kaunas University of Technology, Lithuania email: vishnuvalayil@gmail.com

Thomas Andrew Bryer - PhD in political sciences, professor at the University of Central Florida, USA

email: thomas.bryer@ucf.edu 